\title{
SIGNIFICANCE OF HEAD NURSES - NURSING ADMINISTRATORS' LEADERSHIP STYLES IN HEALTH CARE
}

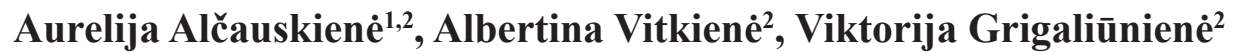 \\ ${ }^{I}$ Department of Nursing, Faculty of Medicine, University of Applied Sciences, Kaunas, Lithuania, \\ ${ }^{2}$ Department of Nursing and Care, Faculty of Nursing, Medical Academy, Lithuanian University of \\ Health Sciences, Kaunas, Lithuania
}

Keywords: nurses-nursing administrators, leadership style, health care.

\begin{abstract}
Summary
The article analyses the significance of Head Nurses - Nursing Administrators leadership styles in health care. Proper leadership is important in every health care organization, Head Nurses need to know and be able to apply a variety of leadership styles. Managers often choose wrong leadership style without appreciating the real situation, which affects the quality of health care, increases patient and employee dissatisfaction, and makes employees less motivated to achieve their goals. Researchers emphasize that Head Nurses must have the knowledge of management science and practice in order to manage the entire department. This article discusses the main three leadership styles: transactional, transformational, and charismatic leadership styles and their principles. There are also four different leadership styles offered in the situational leadership model: directing, coaching, supporting - facilitating and delegating. It is important for managers to acquire emotional and social intelligence, they should encourage innovative thinking for individual and team productivity. Head Nurses through effective leadership styles can complete future challenges by fulfilling the mission and the vision of the health care organization.
\end{abstract}

\section{Introduction}

Effective leadership in health care is critical to the proper management and control of an organization's mission to provide quality and safe health care [1]. Therefore, it is important to know and be able to apply different leadership styles in order to have a successful leadership process [2]. Managers' well-chosen leadership style improves the quality of health care and increases patient care [3] as well as nurses' job satisfaction. [4]. Meanwhile, inappropriate leadership styles - where control is predominant in the physical work environment [5], too high demands and relationships with others at work [6] may lead to chronic fatigue.

\section{Basic leadership styles and principles}

In the scientific literature, three leadership styles are usually distinguished: transactional, transformational, and charismatic.

Individuals in a transactional leadership style are capable of setting goals and communicating them to employees, actively observing, controlling or, conversely, being passive, non-intervening, and avoiding taking responsibility [7]. Petrulis (2014), having analysed the scientific literature on transactional leadership style, points out that the transactional manager demonstrates four qualities: ability to name goals, track activity, provides feedback, plans career.

Another popular leadership style is the transformational leadership style. It is argued that transformational leadership style leaders inspire others with their vision and collaborate with their team as well as identify shared values [8]. It is emphasized that managers of this style demonstrate four dominant qualities that include idealized influence, inspirational motivation, intellectual stimulation, and idealized attitude. Managers of this style try to adapt the existing culture of the organization to a new vision [9].

Charismatic (attractive) leadership style individuals are self-confident and able to convince others [10, 11]. According to Robbins (2010), a charismatic leader has the confidence to have a strong vision that offers a better future than the present, believes in it and is determined to bring about radical changes [11], tend to exalt themselves [12].

Other leadership styles are also highlighted in the scientific literature. Lipinskienè (2012) quoting Levin (1938) distinguishes between autocratic (ruling), democratic (collegial) and liberal (anarchic) leadership styles. Similarly, in the scientific literature there is supportive, achievement-oriented 
and participative leadership styles - set by House (1971) in his Path-Goal Leadership Theory [13].

Supportive leadership style is described as a leadership style that focuses on concern for the needs and well-being of followers. In other words, this style is defined as a leader's behaviour that provides emotional support to employees and includes concerns about employee needs and well-being. Thus, a supportive leadership style focuses more on the social and emotional support that manifests in behaviours such as sympathy, concern, and listening. Compared to a transformational leadership style, it is stated that a transformational leadership style involves greater concern for the organization as a whole, while a supportive leadership style emphasizes personalized, emotional support for subordinates. Empirical research has shown the positive effects of supportive leadership style in organizations - positive relationships between supportive leadership style and follower satisfaction, dedication, innovative behaviour was found [13]. According to A. Petrulis (2017), the most effective leadership style is the combination of all styles. It is stated that no leadership style is ideal in every situation. Leadership styles need to be tailored to the needs of the manager, the staff and the environment [9].

The style of leadership chosen according to the specific circumstances is called the situational leadership approach [14].

The Situational Leadership Style Model offers four different leadership styles: directing, coaching, supporting (facilitating), delegating [15]. A supporting leadership style has already been described, so here's a look at other leadership styles:

Delegating leadership style gives you confidence as the manager recognizes and celebrates employee achievement, and inspires challenge and innovative ways to reach the goal [16]. It is stated that this style supports and allows a high degree of staff autonomy as employees are allowed to engage in planning and administration. In this case, the manager delegates responsibilities to employees to see how the job is progressing. This style is most appropriate when employees are competent and capable of performing tasks and willing and confident in their abilities and knowledge [17].

Directing leadership style. The situation leader, working with followers to model their activities by demonstrating realistic best practices [16], identifies what goal they need to achieve and when it should be achieved. After giving instructions, managers closely monitor their team to make sure its instructions are followed accurately. It is sometimes thought that managers who use this style shout, scream, threaten or intimidate employees, but this is not the case [17].

Coaching leadership style requires the manager to work alongside the follower, providing advice, clarification, and praise while closely following their performance [16]. This style is also appropriate for newly hired employees who have at least several years of work experience [17], and when employees are more responsible, experienced and know exactly what is expected of them [18].

Head Nurses functions affecting the quality of nursing care. The Order of the Minister of Health of the Republic of Lithuania on National Nursing Policy for the time period 2016-2025 confirms the importance of improving the quality of care and patient safety. This means that the Head Nurse must have the knowledge and ability to apply different leadership styles. Researchers emphasize that Head Nurses usually have only nurse education, but they need knowledge of nursing science and practice to manage the entire department. Head Nurses should know how to reason decisions to make employees committed to their work and change, just as nursing efficiency [19]. Scientists believe that acquiring emotional and social intelligence is crucial to becoming a successful Head Nurse and leader, as working in this field involves many different types of people, both colleagues and patients. It is extremely important to be yourself, reflect on your feelings, and think about how emotions can influence actions and relationships (or social interactions). That is why it is so important to learn how to reflect on your clinical experience and how to change the situation through selfawareness or thinking [20].

Laws of the Republic of Lithuania state that Head Nurses - Nursing administrators must understand nursing processes, their management, importance, be able to ensure human resources oriented to the patient and his needs, coordinate the unit's activities, plan activities, be able to make decisions and so on. However, leadership skills are also neglected and underestimated.

Head Nurses need to know and be able to apply different leadership styles as individuals empowering nurses to fulfil their responsibilities by providing an optimal work environment while maintaining a high quality of care and patient safety - in other words, creating an organizational culture that combines high quality health care with patient wellbeing for organizational efficiency and employee efficiency and satisfaction. In health care, organizational success is directly related to the leadership style of Head Nurses. It is stated that nursing managerial leadership styles can contribute to employee engagement through support and encouragement, positive and constructive feedback, open and transparent communication, and personalized approaches [21].

Analysing the most common leadership styles in hospitals, nursing departments, it is noted that the scientific literature indicates that past research on leadership styles in 
hospitals and Head Nurses shows the prevalence of autocratic style [3], however, since the early 1990s, a transformational leadership style has been favoured because Grimm (2010) believes that transformational leadership is more dynamic, and that the health care environment requires leaders who inspire others, create vision rather than reward and punish, making it more suitable for use in modern health care systems [22].

Like Negussie, Demissie (2013), in a study at Jimma University Specialized Hospital in 2012, interviewed 175 nurses and found that transformational leadership style resulted in employee job satisfaction, resulting in improved nurse performance and reduced turnover. [23]

Another study, conducted in 2015, surveyed 273 nursing staff from five hospitals in Eastern Ghana and found that Head Nurses used different leadership styles, depending on the situation, but were more inclined to a supportive leadership style, followed by achievement-oriented leadership style and participative leadership style. The nursing staff exhibited moderate levels of job satisfaction. This means that the Head Nurses demonstrated a situational leadership approach without following a particular style of leadership. This approach has long been recognized as useful in the field of nursing, justifying that nursing provision is a dynamic process [14]. This conclusion is also consistent with other research conducted in Ghana that Ghanaian Head Nurses have different leadership styles but are more prone to a supportive (transformational) leadership style [24]. In addition, the study shows a tendency for Head Nurses to use supportive and achievement-oriented leadership style is also supported by many nursing leadership researchers who emphasized that nurses were gradually moving away from authoritative leadership behaviour and tended to adopt more supportive and achievement-oriented (transactional) leadership style $[25,26]$

Although a study by Azaare and Gross (2011) showed that Ghanaian Head Nurses show a largely autocratic leadership style, this may have led to the qualitative nature of their study.

\section{Conclusions}

1. Having analysed and systematized the data of various Lithuanian and foreign authors, it can be stated that the leadership style - is interrelated leadership methods, norms of behaviour, rules that the Head Nurses uses in his / her work to encourage their staff to achieve their goals.

2. A leadership style is defined as the totality of people's relationships within an organization that are influenced by the manager's values, subordinate expectations, and current situation.
3. Head Nurses should pay attention and make the mission and vision of the hospital clear to each nurse so that they can turn the mission and vision into goals.

4. Head Nurses should understand fully understand set goals and managers should encourage innovative thinking so that existing work standards can be reconsidered for improvement of individual and team productivity.

\section{References}

1. Govender S, Gerwel Proches C.N, Kader A. Examining leadership as a strategy to enhance health care service delivery in regional hospitals in South Africa. J Multidiscip Healthc 2018; 11: 157-166.

https://doi.org/10.2147/JMDH.S151534

2. Dirgèlienè A, Andriekienė R.M. Vadovavimo suaugusiujų švietimo ịstaigai teorinès ir empirinès įžvalgos. Andragogika, 2012; 1(3): 25-48.

3. Bahadori A, Peyrovi H, Ashghali-Farahani M, Hajibabaee F, Haghani $\mathrm{H}$. The relationship between nursing leadership and patient satisfaction. International Journal of Medical Research \& Health Sciences 2016; 5(10):134-141.

4. Yuan S.C, Chou M.C, Chen C.J, Lin Y.J, Chen M.C, Liu HH, et. al. Influences of shift work on fatigue among nurses. Journal of Nursing Management 2011; 19: 339-345.

https://doi.org/10.1111/j.1365-2834.2010.01173.x

5. Hao H, Li L, Shihan Y, Xiaoxing C, Junfeng Z, Hui W. Effects of job conditions, occupational stress, and emotional intelligence on chronic fatigue among Chinese nurses: a cross-sectional study. Psychology Research and Behaviour Management 2019; 12:351-360.

https://doi.org/10.2147/PRBM.S207283

6. Fazzi G, Zamaro N. Exploring the interplay between leadership styles and PSM in two organisational settings. International Journal of Manpower 2016; 37(5): 859-877.

https://doi.org/10.1108/IJM-01-2015-0008

7. Kutkaitis A, Petrulis A. Vadovavimo stilių vertinimas Klaipèdos ugdymo įstaigose. Regional Formation and Development Studies 2014; 1(11): 171-182.

https://doi.org/10.15181/rfds.v12i1.694

8. Xu JH. Leadership theory in clinical practice. Chinese Nursing Research 2017; 4(4): 155-157.

https://doi.org/10.1016/j.cnre.2017.10.001

9. Wagner J. Identifying your leadership strengths and opportunities for growth. [Internet] [cited 2019 Sep 10] Available from: https://leadershipandinfluencingchangeinnursing.pressbooks. com/chapter/chapter-1-identifying-your-leadership-strengthsand-opportunities-for-growth/

10. Khan S, Anjum M. A. Role of leadership style and its impact on getting competitive advantage. European Journal of Applied Sciences 2013; 5(2): 53-61.

11. Šimanskienė L, Petrulis A. Vadovavimo stilių nustatymas 
Klaipėdos miesto progimnazijose. Regional Formation and Development Studies. 2014; 2(13): 107-118

https://doi.org/10.15181/rfds.v13i2.829

12. Karim A.J. The indispensable styles, characteristics and skills for charismatic leadership in times of crisis. International Journal of Advanced Engineering, Management and Science. 2016; 2(5): 363-372.

13. Shin Y. Oh W, Sim C.H, Lee J. A multilevel study of supportive leadership and individual work outcomes: the mediating roles of team cooperation, job satisfaction, and team commitment. Journal of Applied Business Research (JABR). 2016; 32: 55-70. https://doi.org/10.19030/jabr.v32i1.9523

14. Asamani J.A, Naab F, Ofe, A.M.A. leadership styles in nursing management: implications for staff outcomes. Journal of Health Sciences 2016; 6(1):23-36.

https://doi.org/10.17532/jhsci.2016.266

15. Kuchynkova L. Identification of factors associated with leadership style efficiency of managers. Acta Universitatis Agriculturae et Silviculturae Mendelianae Brunensis. 2016; 64212(6): 1971-1980.

https://oi.org/10.11118/actaun201664061971

16. Lynch B. Partnering for performance in situational leadership: a person-centred leadership approach. International Practice Development Journal 2015; 5 (5): 1-10.

https://doi.org/10.19043/ipdj.5SP.007

17. Wahab A. A review of situational leadership theory and relevant leadership styles: options for educational leaders in the $21 \mathrm{st}$ century. Journal of Advances in Social Science and Humanities 2017; 3(11): 36401-36431.

18. Ventresca P. Situational Leadership. Leadership Excellence. 2014; 31(9): 1-13.

https://doi.org/10.12806/V13/I1/RF3

19. Vesterinen S, Suhonen M, Isola A, Paasivaara L, Laukkala H. Nurse managers' perceptions related to their leadership styles, knowledge, and skills in these areas - a viewpoint: case of health centre wards in Finland. ISRN Nursing 2013; 2013: 1-8. https://doi.org/10.1155/2013/951456

20. Gerardi D.J.D. Conflict engagement: emotional and social intelligence. American Journal of Nursing 2015; 115(8): 60-65. https://doi.org/10.1097/01.NAJ.0000470407.66800.e8

21. Wong CA, Cummings GG, Ducharme L. The relationship between nursing leadership and patient outcomes: a systematic review update. J Nurs Manag 2013; 21(5):709-724. https://doi.org/10.1111/jonm.12116

22. Negussie N, Demissie A. Relationship between leadership styles of nurse managers and nurses' job satisfaction in Jimma University Specialized Hospital. Ethiopian Journal of Health Sciences 2013; 23 (1): 49-58.

23. Voon ML, Lo MC, Ngui KS, Ayob NB. The influence of lea- dership styles on employees' job satisfaction in public sector organization in Malaysia. International Journal of Business Management and Social Science 2011;2(5):24-32.

24. Ofei A.M, Sakyi E.K, Buabeng T, Mwini-Nyaledzigbor P, Atindanbila S. Perceived and preferred leadership behavior of nurse managers at the unit level in the Greater Accra Region: a mixed method approach. Int Rev Soc Sci 2014; 2(2): 42-62.

25. Malloy T, Penprase B. Nursing leadership style and psychosocial work environment. J Nurs Manag 2010; 18(6):715-725 https://doi.org/10.1111/j.1365-2834.2010.01094.x

26. Vinkenburg CJ, van Engen ML, Eagly AH, Johannesen-Schmidt MC. An exploration of stereotypical beliefs about leadership styles: is transformational leadership a route to women's promotion? Leadersh Q 2011; 22(1):10-21.

https://doi.org/10.1016/j.leaqua.2010.12.003

\section{VYRESNIUJU SLAUGYTOJU-SLAUGOS ADMINISTRATORIU VADOVAVIMO STILIU REIKŠMĖ SVEIKATOS PRIEŽIŪROJE}

A. Alčauskienè, A. Vitkienè, V. Grigaliūnienè

Raktažodžiai: slaugytojai - slaugos administratoriai, vadovavimo stilius, sveikatos priežiūra.

Santrauka

Straipsnyje pateikiama vyresniujų slaugytojų-slaugos administratorių vadovavimo stilių reikšmé sveikatos priežiūroje. Tinkamas vadovavimas yra svarbus kiekvienoje sveikatos priežiūros organizacijoje. Slaugytojų vadovai turi žinoti ir gebėti taikyti ịvairius vadovavimo stilius. Vadovai, neịvertindami tikros situacijos, pasirenka netinkamą vadovavimo stilių, o nuo to nukenčia sveikatos priežiūros kokybè, padidèja pacientų ir darbuotojų nepasitenkinimas, darbuotojai tampa mažiau motyvuoti siekiant užsibrež̌tu tikslų. Mokslininkai akcentuoja, kad slaugos vadovai turi turèti žinių apie vadybos mokslą ir praktiką, kad galètų valdyti visą skyrių. Straipsnyje aptariami pagrindiniai trys vadovavimo stiliai: transakcinis, transformacinis bei charizmatinis vadovavimo stilius ir ju principai. Taip pat pateikiami situacijos lyderystès stiliaus modelyje siūlomi keturi skirtingi vadovavimo stiliai: nurodantis (ang. directing), parengiantis (ang. coaching), palaikantis (ang. supporting, facilitating), igaliojantis (ang. delegating) vadovavimo stilius. Lyderiams svarbu igyti emocinị ir socialinị intelektą. Siekiant asmens ir komandos produktyvumo, vadovai turètų skatinti novatorišką mąstymą. Vyresnieji slaugytojai-slaugos administratoriai, pasitelkę efektyvius vadovavimo stilius, gali išspręsti ateities iššūkius, igyvendinant sveikatos priežiūros organizacijos misiją ir viziją. Adresas susirašinèti: albertina@mg-group.lt

Gauta 2019-11-22 